\title{
Hydrological dynamics of water sources in a Mediterranean lagoon
}

\author{
C. Stumpp ${ }^{1}$, A. Ekdal ${ }^{2}$, I. E. Gönenc ${ }^{3}$, and P. Maloszewski ${ }^{1}$ \\ ${ }^{1}$ Helmholtz Zentrum München, German Research Center for Environmental Health, Institute of Groundwater Ecology, \\ Neuherberg, Germany \\ ${ }^{2}$ Istanbul Technical University, Environmental Engineering Department, Maslak, Istanbul, Turkey \\ ${ }^{3}$ IGEM Research \& Consulting Co., Istanbul, Turkey
}

Correspondence to: C. Stumpp (christine.stumpp@ @elmholtz-muenchen.de)

Received: 31 May 2014 - Published in Hydrol. Earth Syst. Sci. Discuss.: 1 July 2014

Revised: 10 October 2014 - Accepted: 30 October 2014 - Published: 5 December 2014

\begin{abstract}
Lagoons are important ecosystems occupying large coastal areas worldwide. Lagoons contain various mixtures of marine and freshwater sources which are highly dynamic in time. However, it often remains a challenge to identify and quantify dynamic changes of water sources, particularly in heterogeneous lagoon systems like the KöycegizDalyan lagoon (KDL), which is located at the south-west of Turkey on the Mediterranean Sea coast. The objective of this study was to quantify different contributions of potential water sources i.e. surface water, groundwater and seawater in the lagoon and how these water sources changed over time and space. In the wet- and dry-season stable isotopes of water, chloride concentration $\left(\mathrm{Cl}^{-}\right)$and salinity were measured in two depths in the lagoon and surrounding water bodies (sea, lake, groundwater). Different components of water sources were quantified with a three component endmember mixing analysis. Differences in $\mathrm{Cl}^{-}$and stable isotopes over time indicated the dynamic behaviour of the system. Generally, none of the groundwater samples was impacted by water of the Mediterranean Sea. During the wet season, most of the lagoon water (>95\%) was influenced by freshwater and vertically well mixed. During the dry season, high $\mathrm{Cl}^{-}$ in the deeper sampling locations indicated a high contribution of marine water throughout the entire lagoon system due to saltwater intrusion. However, a distinct layering in the lagoon was obvious from low $\mathrm{Cl}^{-}$and depleted isotope contents close to the surface supporting freshwater inflow into the system even during the dry season. Besides temporal dynamics also spatial heterogeneities were identified. Changes in water sources were most evident in the main lagoon channel compared to more isolate lagoon lakes, which were influenced by marine water even in the wet season, and compared
\end{abstract}

to side branches indicating slower turnover times. We found that environmental tracers helped to quantify highly dynamic and heterogeneous contributions of different water sources in the Köycegiz-Dalyan lagoon.

\section{Introduction}

Lagoons are important ecosystems occupying $13 \%$ of the coastal areas worldwide (Barnes, 1980). Along the Mediterranean coastline, more than 100 lagoons are found but only little hydrological and biological data of most of these ecosystems are available (Pérez-Ruzafa et al., 2011a). Generally, lagoons are shallow, coastal water bodies with marine water influence. Mostly they have limited connectivity to the open sea through coastal barriers or connecting inlets. Further freshwater input can come from upstream rivers or groundwater. Lagoons are important ecosystems being a habitat for rare species like seagrass, fishes and turtles, and with a high productivity and diversity (Alongi, 1998; PérezRuzafa et al., 2011b; Remane and Schlieper, 1971). Lagoons not only are valued for fauna and flora, but also due to recreational and industrial purposes by society. These societal values are, however, difficult to quantify (Anthony et al., 2009) also due to conflicts of interest in lagoon ecosystems (fishery, aquaculture, tourism) (Pérez-Ruzafa et al., 2011a). Particularly in the context of global change lagoon ecosystems require a proper management for a sustainable use and to protect the ecosystem (Kløve et al., 2014; Anthony et al., 2009). Here, management must not impact the quality and quantity of the lagoon water in terms of chemical and ecological status on the one hand. On the other hand, also groundwater 
management (drinking water/irrigation) must not impact lagoons depending on groundwater and vice versa. For example, pumping of groundwater can influence the quality of the withdrawn drinking/irrigation water due to increased marine water influence or due to the mobilization of groundwater from deeper layers. In addition, groundwater withdrawal can change the fraction of freshwater source in the lagoon water body which strongly would influence its functions as a habitat for species specifically adapted to the environment. This example highlights the vulnerability of lagoon systems. It shows the strong need to protect and manage these ecosystems and to identify seawater intrusions and groundwater dependencies in the lagoon catchment area.

Here, a detailed knowledge about the water sources and water dynamics in lagoon ecosystems is fundamental before studying further ecological and chemical processes. It has been shown that lagoon systems are heterogeneous and dynamic systems. The quality of the water and subsequent seawater quality or adjacent groundwater quality strongly depends on the water flow and origin of water and nutrients (Gattacceca et al., 2009; Niencheski et al., 2007; Santos et al., 2008a, b). Land use can impact the interaction of lagoon with surrounding groundwater resulting in lagoon infiltration processes under pine tree plantations compared to negligible interactions under natural dune vegetation (Schmidt et al., 2011). Such spatial impacts can be identified using environment tracer methods. Further, they can also be used to study temporal dynamics of water sources and hydrological processes like seasonal changes in evaporation and seawater contribution (Lecuyer et al., 2012; Schmidt et al., 2011). Salinity and stable isotopes of water were used to identify spatiotemporal changes of water in the Akyatan lagoon, Turkey (Lecuyer et al., 2012). Assuming two different end members, river and seawater, it was found that in the wet season the contribution of freshwater and seawater was 62 and $38 \%$ on average. Throughout spring to autumn, progressive evaporation of lagoon water results in hypersaline conditions with strongly enriched isotope values suggesting limited input of freshwater in the system (Lecuyer et al., 2012). Still, it remains unknown in many lagoon systems what the contribution of different water sources is and how they change not only over time, i.e. wet and dry seasons, but also over space, i.e. both horizontal, spatial locations in the lagoon and vertical, depth locations in the lagoon; the latter is of particular interest in wetland type lagoon systems or lagoons with stratification expecting poorly mixed hydrological systems. Therefore, the objective of the current study was (i) to identify and quantify different water sources in a lagoon, (ii) how they change over time and space, and (iii) thus how heterogeneous and dynamic the hydrology of the lagoon and adjacent groundwater was. We achieved these objectives by applying environmental tracer methods and developing a three component endmember mixing approach. Different sources of water (seawater, groundwater, lake water) were identified at different locations in the lagoon, including top and bot-
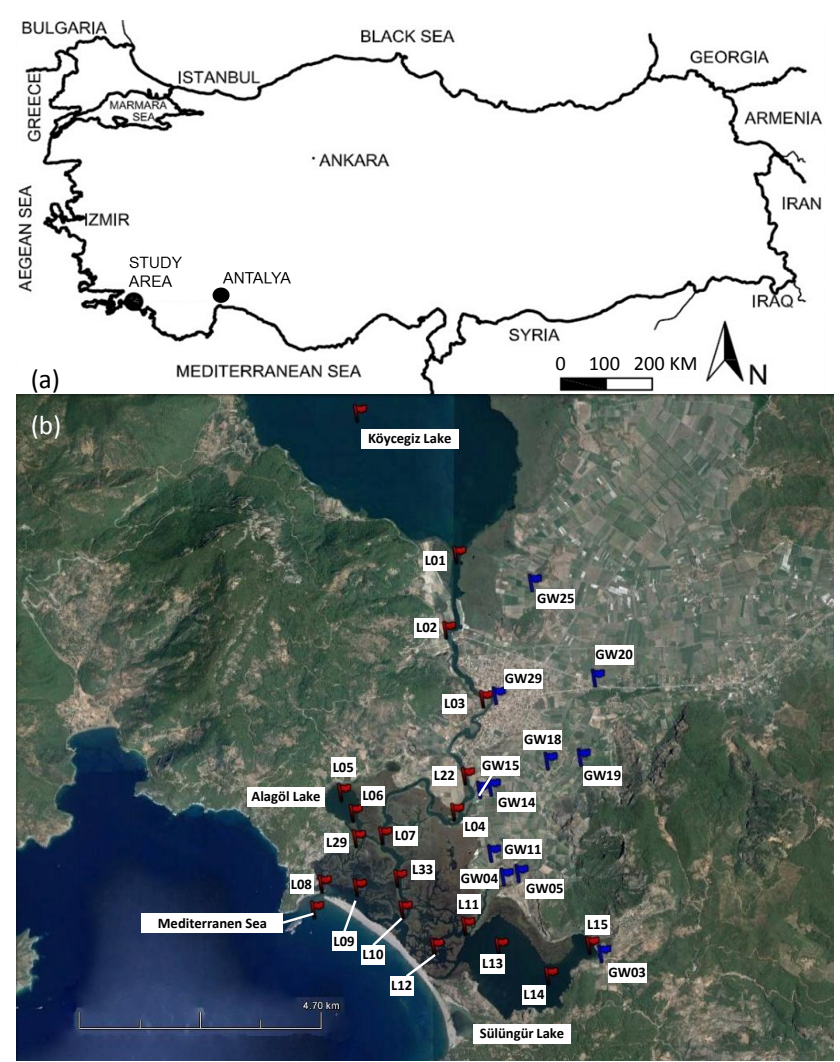

Figure 1. Geographic location of the Köycegiz-Dalyan coastal lagoon (a) and sampling locations (b); source of modified satellite picture was Google Earth (2014).

tom water column depths, for wet and dry season. Thus, the novelty of this study is to present an environmental tracer method identifying and quantifying both temporal dynamics (wet and dry season) and spatial heterogeneities (depth of the water column and distance to coastline) of water sources in a wetland type lagoon system. With improved, detailed understanding of heterogeneous and dynamic hydrological processes in groundwater influenced lagoon ecosystems, targeted strategies to better manage may be developed.

\section{Material and methods}

\subsection{Study area}

Köycegiz-Dalyan coastal lagoon is located at the southwest of Turkey on the Mediterranean Sea coast within the province of Mugla (Fig. 1a). The geology in this region is mainly composed of allochthonous and authochthounous Flysch and karstic facies overlain by plio-quaternary sediments (Graciansky, 1968). Due to tectonic activities, several faults were formed in this area. Details about the geology and more maps can be found in Bayari et al. (1995). 


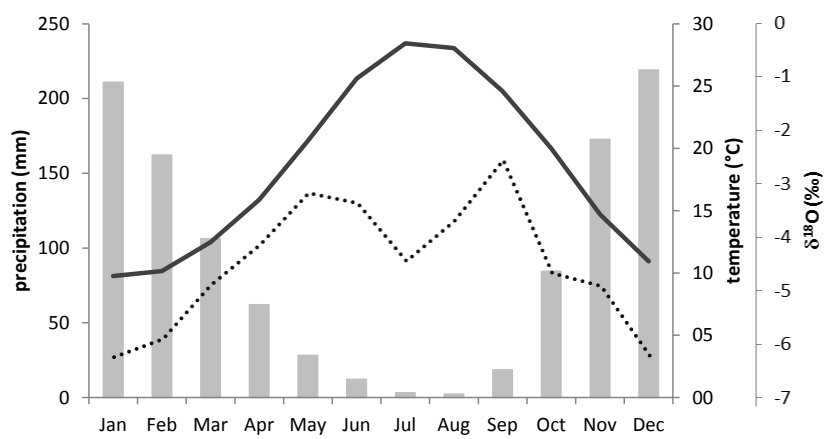

Figure 2. Long-term monthly data of average precipitation (grey bars) and air temperature (solid line) from Köycegiz meteorology station (1976-2010) and isotopic composition of precipitation in Antalya (dashed line). Data from Antalya are available at the IAEA database WISER (http://www-naweb.iaea.org/napc/ih/index.html, last access: 19 May 2014).

The total area of the watershed of Köycegiz Lake is approximately $830 \mathrm{~km}^{2}$ and of the lagoon is $130 \mathrm{~km}^{2}$. The upstream located Köycegiz Lake ( $2 \mathrm{~m}$ a.s.l.) is directly connected through surface water with the lagoon and further to the Mediterranean Sea by the lagoon and its various branches (Fig. 1b). The discharge from the Köycegiz Lake is $33 \mathrm{~m}^{3} \mathrm{~s}^{-1}$ on average with up to $110 \mathrm{~m}^{3} \mathrm{~s}^{-1}$ during winter times (Bayari et al., 2001). During winter, most of the branches in the wetland areas in the lagoon are connected. In summer, Köycegiz Lake water level decreases $(-0.9 \mathrm{~m})$ reducing the hydraulic gradient to the Mediterranean Sea considerably. The depth of the main Dalyan channel decreases from $5 \mathrm{~m}$ upstream near the lake to about $1 \mathrm{~m}$ downstream near the sea. In addition to the Dalyan Channel and its branches, the lagoon also includes the lakes Alagöl and Sülüngür. Maximum depths of these lakes are 4 and $13 \mathrm{~m}$, respectively. Aquaculture activities are conducted in Sülüngür Lake. Both, Köycegiz Lake and the Köycegiz-Dalyan coastal lagoon are part of the area declared as a special protection area in 1988, as it is a unique and important ecosystem with a high diversity of species. It hosts one of the rare breeding and nesting sites for endangered sea turtles, caretta caretta, and possesses the ruins of Ancient City of Caunos and 4th century BC Lycian rock tombs that are found near the seaside by the river (Gurel et al., 2005). Groundwater is used as irrigation and drinking water in the area. We expect that the groundwater is mainly recharged locally from the surrounding forested mountains (up to $565 \mathrm{~m}$ a.s.l.; Fig. 1) of the karstic areas. The main sectors driving the economy in the watershed are agriculture, tourism and forestry. Aquaculture and capture fishing are among the important beneficial uses of the lagoon together with recreational activities.

The area is under the influence of typical Mediterranean climate characteristics, with a hot, dry summer season and a warm, rainy winter season with mean annual air temperatures of $18.3^{\circ} \mathrm{C}$ and mean annual precipitation of $1083 \mathrm{~mm}$. (a)

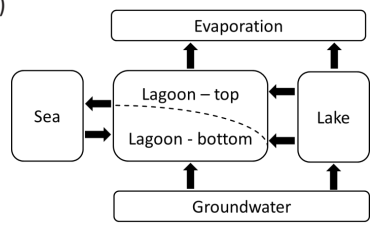

(b)

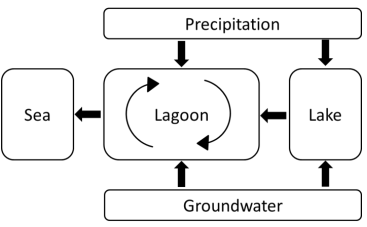

Figure 3. Conceptual model of flow connections between the lagoon and surrounding water bodies for (a) the dry and (b) wet season.

These data were taken in the study area from the State Meteorology Services of Turkish Republic for Köycegiz Meteorology Station covering the period 1976-2010, and monthly averages are presented in Fig. 2. Thus, precipitation usually occurs during the cold winter period and drought condition prevails during the hot summer period.

An environmental isotopic and hydrochemical study was conducted by Bayari et al. (1995) for determination of the dynamics of the upstream Köycegiz Lake. Köycegiz and Sultaniye are the two major basins that comprise Köycegiz Lake. According to their statements the important sources that feed the lake are mainly alluvial groundwater, streamwater (Namnam and Yuvarlakçay), and rain. The main components of outflow from the lake are discharge to Mediterranean Sea through the Dalyan Channel and evaporation from the lake surface. Their environmental isotopic data and chemical data indicate that rainfall and stream flow are low density waters and thermal groundwater is the high density water; complete annual mixing cannot be observed due to the density effects. The main geothermal inflow at the southern lake coast (Sultaniye Basin) is the Sultaniye spring. It is located at a depth of 8-10 $\mathrm{m}$ and about $4 \mathrm{~km}$ north-west of the lake exit into the Dalyan channel which is shallow (0-6 m) (Bayari et al., 2001); too shallow for receiving any geothermal influenced water from the Sultaniye Basin.

\subsection{Conceptual model}

Identifying different water sources in the lagoon we set up a conceptual model distinguishing between dry (Fig. 3a) and wet seasons (Fig. 3b). For the dry season our hypothesis was that evaporation results in low water tables in the lagoon favouring both fluxes from Köycegiz Lake and the sea into the lagoon. However, higher water levels maintain in the main Dalyan channel with freshwater flow from Köycegiz Lake to the sea. Thus, we expected density driven layering in the lagoon with (i) freshwater input from the lake in the top layer, which is influenced by evaporation, and (ii) saltwater input in the bottom layer mixed with groundwater (Fig. 3a). We further expected that the seawater influence decreases with distance to the coastline. For the wet season our hypothesis was that freshwater input, mainly from groundwater and lake during baseflow conditions and additionally from precipitation during events, results in high wa- 
ter tables in the lagoon favouring freshwater flow from the lake through the lagoon into the sea. We expected the lagoon water to be well mixed without distinct density driven layering (Fig. 3b). For both seasons, we excluded any direct influence of the geothermal Sultaniye spring to the lagoon, because the spring's influence was found only for the bottom layers of the Köycegiz Lake (Bayari et al., 1995) not outflowing into the shallow Dalyan channel and the lagoon but discharging northwards. Still, other unknown geothermal springs in the lagoon cannot be excluded.

\subsection{Sampling campaigns}

To quantify the different contributions of potential water sources like surface water, groundwater and seawater in the lagoon and how these water sources change over time and space, two sampling campaigns were conducted one representing the dry season (July 2011) and the other one representing the wet season (March 2012). Sampling in both seasons was without major antecedent rain events. Consequently, precipitation as major source in the lagoon can be neglected. Particularly in the wet season, water residence times in the lagoon are short due to high outflow rates from the lake (up to $110 \mathrm{~m}^{3} \mathrm{~s}^{-1}$; Bayari et al., 2001) and which is also supported by modeling results of Ekdal (2008) indicating residence times $<2$ days for the wet season in the main lagoon channel.

Water samples were taken in the lagoon along the main channel (L1, L2, L3, L22, L4, L7, L33, L10, L29, L9, L8), surrounding lakes (L5, L13, L14) and their inflow/outflow connections to the lagoon system (L6, L11, L12, L15) as well as in the Köycegiz Lake and Mediterranean Sea in two depths at the top (T), just below the surface, and at the very bottom (B). The samples were taken by boat used for transportation from Dalyan town to Iztuzu Beach, except for Sülüngür Lake. Since aquaculture activities are conducted in this lake boat of the fishing cooperative was used for sampling. Further samples were taken from surrounding groundwater wells. Groundwater samples were taken with the pump of the well, which is used for abstracting water. In total, samples were taken at 18 lagoon, 11 groundwater locations, as well as at one sea location and one lake location (Fig. 1b), which were further analysed for chemical analysis.

\subsection{Water isotopes and chemical analysis}

Water samples were analysed for $\delta^{18} \mathrm{O}( \pm 0.15 \% \circ)$ and $\delta^{2} \mathrm{H}$ $( \pm 1 \%$ ) contents without any pre-treatment of the samples using a water isotope analyser (L2120-i, Picarro Inc., Santa Clara, CA, USA). The contents are given in the delta notation as $\delta$-value $(\% o)$, which is the relative deviation of the sample from the V-SMOW (Vienna-Standard Mean Ocean Water). The results of the stable water isotope analysis from the observation area were compared to public available isotope contents in precipitation ac- cessible through the IAEA (International Atomic Energy Agency) web database WISER (http://www-naweb.iaea.org/ napc/ih/IHS_resources_isohis.html; 2014). Here, Antalya is the closest location of the Global Network of Isotopes in Precipitation (GNIP) having long-term isotope records in precipitation, which is $200 \mathrm{~km}$ east of the studied lagoon and $49 \mathrm{~m}$ asl. Based on these data, the local meteoric water line (LMWL; $\delta^{2} \mathrm{H}=8 \delta^{18} \mathrm{O}+14.3$ ) and the annual weighed average isotope contents in precipitation $\left(\delta^{18} \mathrm{O}=-4.9 \%\right.$; $\delta^{2} \mathrm{H}=-24.9 \%$ ) were calculated; monthly long-term weighed averages are shown in Fig. 2.

Chloride concentrations $\left( \pm 0.22 \mathrm{mg} \mathrm{L}^{-1}\right)$ were measured by using Merck test kits (catalog number 1.14897.0001). $\mathrm{NaCl}$ stock solution, which has $1 \mathrm{mg} \mathrm{Cl}-$ in $1 \mathrm{~mL}$, was used in order to prepare standard solutions for controlling the reliability of chloride measurements carried out with Merck test kits. Salinity measurements $\left( \pm 0.1 \mathrm{mg} \mathrm{L}^{-1}\right)$ were conducted in situ with a YSI 6600V2 Multiparameter Water Quality Sonde.

\subsection{Endmember mixing analysis}

Calculating different water fractions in the lagoon system (top and bottom), three endmembers were defined that differed in isotopic composition and chloride concentrations/salinity: (i) Köycegiz Lake water, (ii) groundwater, and (iii) Mediterranean seawater. The concentrations (C) of the endmembers were defined for both seasons separately. For lake $\left(C_{\mathrm{LW}}\right)$ and seawater $\left(C_{\mathrm{SW}}\right)$, the surface near water samples were taken and for groundwater an average concentration $\left(C_{\mathrm{GW}}\right)$ was calculated from all groundwater wells without considering GW011 due to increased chloride concentrations compared to other groundwater locations. Thus, the isotope contents $\left({ }^{18} \mathrm{O}\right)$ and chloride concentrations $\left(\mathrm{Cl}^{-}\right)$or salinity $(\mathrm{S})$ in the lagoon $\left(C_{\mathrm{Lag}}\right)$ were calculated from the three component mixing analysis:

$$
\begin{aligned}
& C_{\mathrm{Lag}_{18} \mathrm{O}}=f_{\mathrm{GW}} \cdot C_{\mathrm{GW}_{18} \mathrm{O}}+f_{\mathrm{LW}} \cdot C_{\mathrm{LW}_{18 \mathrm{O}}}+f_{\mathrm{SW}} \cdot C_{\mathrm{SW}_{18 \mathrm{O}}} \\
& C_{\mathrm{Lag}_{\mathrm{Cl}}}=f_{\mathrm{GW}} \cdot C_{\mathrm{GW}_{\mathrm{Cl}}}+f_{\mathrm{LW}} \cdot C_{\mathrm{LW}_{\mathrm{Cl}}}+f_{\mathrm{SW}} \cdot C_{\mathrm{SW}_{\mathrm{Cl}}} \\
& C_{\mathrm{Lag}_{\mathrm{S}}}=f_{\mathrm{GW}} \cdot C_{\mathrm{GW}_{\mathrm{S}}}+f_{\mathrm{LW}} \cdot C_{\mathrm{LW}_{\mathrm{S}}}+f_{\mathrm{SW}} \cdot C_{\mathrm{SW}_{\mathrm{S}}} \\
& 1=f_{\mathrm{GW}}+f_{\mathrm{LW}}+f_{\mathrm{SW}}
\end{aligned}
$$

where $f$ refers to the fraction of groundwater $(\mathrm{GW})$, lake water (LW), and seawater (SW), respectively. Getting information about the uncertainty of the method, we calculated the mixing ratios based on two different approaches considering simultaneously $\delta^{18} \mathrm{O}$ (Eq. 1) and $\mathrm{Cl}^{-}$(Eq. 2) or $\delta^{18} \mathrm{O}$ (Eq. 1) and salinity (Eq. 3), both in combination with Eq. (4).

\section{Results}

\subsection{Stable isotopes of water}

Results of stable isotope analyses are presented in Table 1. All analysed water samples plotted close or below 

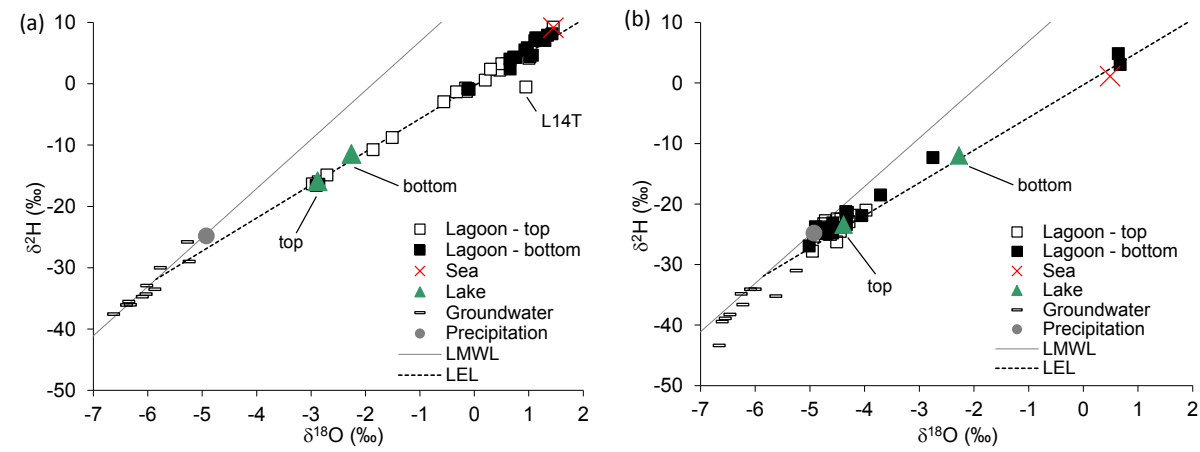

Figure 4. Dual isotope plot for (a) dry season and (b) wet season sampling campaign; LMWL and average precipitation taken from closest station of the GNIP data base i.e. Antalya.

the LMWL for both the dry (Fig. 4a) and wet seasons (Fig. 4b). Groundwater samples were the most depleted samples ranging from -6.7 to $-5.2 \%$ for $\delta^{18} \mathrm{O}$, and were even lower compared to average precipitation contents $(-4.9 \%$ o for $\delta^{18} \mathrm{O}$ ). Assuming only negligible differences in isotopic composition of precipitation between Antalya and our observation area due to close proximity and similar location on the Mediterranean Sea, these differences support our assumption of higher altitude precipitation from surrounding mountains as major recharge source of groundwater. Average differences in elevation $(400 \mathrm{~m})$ and isotope contents $\left(1.17 \%\right.$ for $\delta^{18} \mathrm{O} ; 9.9 \%$ for $\left.\delta^{2} \mathrm{H}\right)$ give an altitude gradient of $0.29 \% / 100 \mathrm{~m}$ for $\delta^{18} \mathrm{O}\left(2.5 \% \mathrm{o} / 100 \mathrm{~m}\right.$ for $\left.\delta^{2} \mathrm{H}\right)$. These gradients are in accordance with values reported for the southern Adriatic region $(0.24 \% / 100 \mathrm{~m}$; Vreca et al., 2006), the global and Italian gradients $(0.2 \% / 100 \mathrm{~m}$; Bowen and Wilkison, 2002; Longinelli and Selmo, 2003) and simulated values for the Mediterranean Sea region (Lykoudis and Argiriou, 2007).

In groundwater, more depleted contents were generally observed in the wet season compared to the dry season; however, absolute differences between seasons were small $\left(0.21 \%\right.$ o for $\delta^{18} \mathrm{O} ; 2.8 \%$ o for $\left.\delta^{2} \mathrm{H}\right)$. These differences can either result from a fraction of local seepage water with short residence times, from influence of seawater or from uncertainties of groundwater sampling. Well screening depths were unknown and therefore we expected some minor uncertainties when taking groundwater samples, i.e. water from same depths and taken with same flow rates during sampling.

Isotope contents of seawater were positive with more enriched contents in dry $\left(1.5 \%\right.$ for $\left.\delta^{18} \mathrm{O}\right)$ compared to wet seasons $\left(0.5 \%\right.$ ofor $\left.\delta^{18} \mathrm{O}\right)$. All Köycegiz Lake water samples plotted below the LMWL (Fig. 4) indicating enrichment due to evaporation and potential geothermal water origin as found in previous studies (Bayari et al., 1995, 2001). When considering isotope contents of reported geothermal origin in the area $(-0.81,-4.87,-4-76 \%$, and $-2.9,-30.0,-27.2 \%$ o for $\delta^{18} \mathrm{O}$ and $\delta^{2} \mathrm{H}$, respectively; Bayari et al., 1995), it is evident that the geothermal origin is hidden in the evapo- ration signal and therefore these two sources cannot be distinguished considering isotope contents only. Additionally, a local evaporation line (LEL) was determined considering the top lake samples for both seasons only. The resulting LEL $\left(\delta^{2} \mathrm{H}=5.40 \delta^{18} \mathrm{O}-0.3\right)$ is similar to another Turkish lagoon $\left(\delta^{2} \mathrm{H}=5.29 \delta^{18} \mathrm{O}-0.55\right.$; Lecuyer et al. 2012). It intersects the LWML in $\delta^{18} \mathrm{O}=-5.85 \%$ o $\left(\delta^{2} \mathrm{H}=-31.9 \%\right.$ ), which is also close to the average groundwater contents $\left(\delta^{18} \mathrm{O}=-6.08 \% ; ; \delta^{2} \mathrm{H}=-34.84 \%\right.$ ) supporting assumption of higher elevation recharge area for the catchment.

Water samples from the lagoon mainly plotted on/below the LMWL and between groundwater and seawater samples. Distinct differences in isotopic contents were found (i) for the dry (Fig. 4a) and wet seasons (Fig. 4b) indicating a seasonally dynamic water body and (ii) for samples close to the surface (open squares, Fig. 4) and the bottom of the lagoon (closed square, Fig. 4) indicating a layered vs well mixed system in the dry and wet seasons, respectively. Particularly in the dry season, differences between top and bottom lagoon samples were obvious. Here, most interestingly, water samples at the bottom of the lagoon were more enriched compared to top water samples. This clearly indicates that the enrichment was not caused by evaporation but rather by mixing with enriched seawater which is more pronounced at the bottom due to saltwater density effects. In the wet season, similar isotope contents were found for top and bottom samples except for samples from Alagöl (L5; $\left.-2.7 \%, \delta^{18} \mathrm{O}\right)$ and Sülüngür Lake (L13, L14; +0.64-0.68\%o, $\delta^{18} \mathrm{O}$ ) which had more enriched isotope contents at the bottom only. Here, top water samples showed similar ranges in isotope contents $\left(-4.5\right.$ to $\left.-4.0 \%, \delta^{18} \mathrm{O}\right)$ compared to other lagoon samples $\left(-5.0\right.$ to $-4.0 \%$ o, $\left.\delta^{18} \mathrm{O}\right)$.

\subsection{Chloride vs. stable isotopes of water}

Results of geochemical analysis are given in Table 1. Chloride and salinity showed similar spatiotemporal results and therefore, chloride results are discussed in more detail only. Chloride concentrations were in line with the results of stable isotope of water. Chloride was lowest in groundwater 
Table 1. Chemical analyses of water samples for the dry and wet seasons; asterisks indicate values used for endmember mixing analysis using either a three (3EMMA) or two (2EMMA) mixing approach.

\begin{tabular}{|c|c|c|c|c|c|c|c|c|c|c|}
\hline \multirow[b]{2}{*}{ Location } & \multicolumn{5}{|c|}{ Dry season } & \multicolumn{5}{|c|}{ Wet season } \\
\hline & Depth & Chloride & Salinity & $\delta^{18} \mathrm{O}$ & $\delta^{2} \mathrm{H}$ & Depth & Chloride & Salinity & $\delta^{18} \mathrm{O}$ & $\delta^{2} \mathrm{H}$ \\
\hline & (m) & $\left(\mathrm{mg} \mathrm{L}^{-1}\right)$ & $\left(\mathrm{g} \mathrm{L}^{-1}\right)$ & $(\% o)$ & $(\% \circ)$ & (m) & $\left(\mathrm{mg} \mathrm{L}^{-1}\right)$ & $\left(\mathrm{g} \mathrm{L}^{-1}\right)$ & $(\% \circ)$ & $(\% o)$ \\
\hline L01T & 0.1 & 2400 & 3.8 & -2.90 & -16.4 & 0.1 & 930 & 3.1 & -4.70 & -24.9 \\
\hline $\mathrm{L} 02 \mathrm{~T}$ & 0.1 & 2600 & 3.8 & -2.87 & -16.0 & 0.1 & 930 & 3.1 & -4.51 & -26.3 \\
\hline L03T & 0.1 & 2800 & 4.0 & -2.97 & -16.4 & 0.1 & 930 & 3.2 & -4.78 & -24.8 \\
\hline L04T & 0.1 & 3700 & 7.0 & -2.71 & -14.9 & 0.1 & 940 & 3.0 & -4.93 & -25.4 \\
\hline L05T & 0.1 & 11400 & 23.6 & -0.15 & -1.3 & 0.1 & 2350 & 4.6 & -4.50 & -22.5 \\
\hline L06T & 0.1 & 14900 & 22.3 & -0.16 & -0.7 & 0.1 & 1500 & 4.2 & -4.72 & -22.8 \\
\hline L07T & 0.1 & 7800 & 16.1 & -1.86 & -10.8 & 0.1 & 1050 & 3.2 & -4.68 & -24.8 \\
\hline L08T & 0.1 & 18600 & 37.9 & 1.45 & 9.2 & 0.1 & 1300 & 4.2 & -4.74 & -23.3 \\
\hline L09T & 0.1 & 14700 & 29.3 & 0.59 & 3.3 & 0.1 & 1300 & 4.5 & -4.44 & -24.5 \\
\hline L10T & 0.1 & 14700 & 27.6 & 0.47 & 2.2 & 0.1 & 840 & 3.4 & -4.76 & -24.7 \\
\hline L11T & 0.1 & 15800 & 27.6 & 0.30 & 2.4 & 0.1 & 2150 & 5.9 & -4.95 & -27.8 \\
\hline $\mathrm{L} 12 \mathrm{~T}$ & 0.1 & 13200 & 25.7 & 0.20 & 0.6 & 0.1 & 2500 & 6.9 & -4.28 & -22.9 \\
\hline L13T & 0.1 & 18200 & 30.6 & 1.00 & 4.2 & 0.1 & 1400 & 7.6 & -4.17 & -21.9 \\
\hline L14T & 0.1 & 17400 & 30.6 & 0.95 & -0.6 & 0.1 & 1350 & 7.6 & -3.97 & -21.0 \\
\hline L15T & 0.1 & 13900 & - & -0.33 & -1.3 & 0.1 & 1200 & 7.3 & -4.43 & -22.5 \\
\hline L22T & 0.1 & 8700 & 16.7 & -1.51 & -8.8 & 0.1 & 950 & 3.2 & -4.73 & -24.4 \\
\hline L29T & 0.1 & 13700 & 29.3 & 0.50 & 3.2 & 0.1 & 750 & 3.3 & -4.62 & -25.0 \\
\hline L33T & 0.1 & 12000 & 25.0 & -0.56 & -2.9 & 0.1 & 950 & 3.4 & -4.76 & -23.8 \\
\hline L01B & 3.8 & 3300 & 26.3 & -2.86 & -16.4 & 3.8 & 940 & 3.1 & -4.73 & -24.7 \\
\hline L02B & 4.4 & 3600 & 27.8 & -0.12 & -0.8 & 4.4 & 940 & 3.2 & -4.7 & -24.4 \\
\hline L03B & 2.5 & 3700 & 31.8 & -2.90 & -16.6 & 2.4 & 950 & 3.2 & -4.7 & -24.8 \\
\hline L04B & 2.1 & 20000 & 32.7 & 0.73 & 4.3 & 2.0 & 970 & 3.1 & -5.01 & -27.0 \\
\hline L05B & 3.3 & 22300 & 38.2 & 1.43 & 8.1 & 3.2 & 7100 & 19.4 & -2.7 & -12.3 \\
\hline L06B & 1.4 & 12800 & 32.1 & -0.09 & -0.9 & 1.7 & 1600 & 4.7 & -4.58 & -23.1 \\
\hline L07B & 2.0 & 21400 & 35.8 & 1.13 & 7.5 & 1.9 & 1100 & 3.1 & -4.90 & -23.8 \\
\hline L08B $* 2$ EMMA & 1.1 & 23800 & 39.7 & 1.16 & 7.4 & 1.1 & 1300 & 4.3 & -4.44 & -23.9 \\
\hline L09B & 1.3 & 24200 & 39.0 & 1.35 & 7.9 & 1.2 & 1700 & 5.4 & -4.33 & -23.4 \\
\hline L10B & 1.1 & 21800 & 33.8 & 1.30 & 7.1 & 1.3 & 930 & 3.4 & -4.78 & -24.0 \\
\hline L11B & 1.5 & 17100 & 31.2 & 1.02 & 4.4 & 1.5 & 3500 & 7.5 & -4.34 & -21.3 \\
\hline L12B & 1.5 & 14300 & 34.6 & 0.66 & 2.4 & 1.5 & 3600 & 7.3 & -4.31 & -21.4 \\
\hline L13B & 3.4 & 18300 & 36.5 & 1.07 & 4.6 & 3.6 & 21600 & 41.2 & 0.64 & 4.9 \\
\hline L14B & 5.4 & 18100 & 36.9 & 0.76 & 4.3 & 5.4 & 21000 & 41.2 & 0.68 & 3.0 \\
\hline L15B & 1.6 & 16400 & - & 0.65 & 4.0 & 1.6 & 1320 & 8.0 & -4.05 & -21.9 \\
\hline L22B & 3.0 & 22100 & 35.9 & 0.97 & 5.9 & 3.0 & 980 & 3.3 & -4.66 & -24.8 \\
\hline L29B & 1.8 & 17500 & 35.5 & 0.93 & 5.5 & 1.8 & 850 & 3.3 & -4.58 & -24.8 \\
\hline L33B & 3.8 & 19800 & 38.8 & 1.11 & 7.0 & 3.8 & 3400 & 11.3 & -3.71 & -18.5 \\
\hline GW03 & - & 132 & 0.4 & -5.27 & -25.8 & - & - & - & - & - \\
\hline GW04 & - & 117 & 0.4 & -6.10 & -34.7 & - & 111 & 0.4 & -6.08 & -34.1 \\
\hline GW05 & - & 146 & 0.5 & -6.03 & -34.3 & - & 88 & 0.4 & -6.25 & -34.8 \\
\hline GW11 & - & 2300 & 1.3 & -6.39 & -36.1 & - & 460 & 1.1 & -6.66 & -43.4 \\
\hline GW14 & - & 69 & 0.3 & -6.35 & -35.5 & - & 41 & 0.3 & -6.46 & -38.3 \\
\hline GW15 & - & 41 & 0.3 & -6.32 & -36.0 & - & 40 & 0.3 & -6.22 & -36.6 \\
\hline GW18 & - & 42 & 0.4 & -6.02 & -32.9 & - & 16 & 0.5 & -5.62 & -35.2 \\
\hline GW19 & - & 25 & 0.3 & -6.63 & -37.6 & - & - & 0.3 & -6.55 & -38.9 \\
\hline GW20 & - & 56 & 0.4 & -5.77 & -30.0 & - & 18 & 0.2 & -6.60 & -39.5 \\
\hline GW25 & - & 57 & 0.6 & -5.24 & -29.0 & - & 50 & 0.5 & -5.25 & -31.0 \\
\hline GW29 & - & 46 & 0.4 & -5.87 & -33.5 & - & 26 & 0.4 & -6.00 & -34.1 \\
\hline $\mathrm{GW}^{*}$ & - & 73 & 0.4 & -6.00 & -32.9 & - & 49 & 0.4 & -6.17 & -36.6 \\
\hline Sea $* 3$ EMMA & 0.1 & 20800 & 40.0 & 1.45 & 9.1 & 0.1 & 21700 & 39.2 & 0.49 & 1.1 \\
\hline Lake* & 0.1 & 2200 & 3.7 & -2.88 & -15.9 & 0.1 & 920 & 3.2 & -4.38 & -23.4 \\
\hline Lake & 12.8 & 4500 & 11.2 & -2.26 & -11.5 & 12.7 & 4800 & 13.6 & -2.27 & -12.0 \\
\hline
\end{tabular}


samples for both sampling times suggesting no or negligible seawater influence for most of these groundwater locations. Only one sampling site (GW11) showed increased chloride concentrations $\left(460 \mathrm{mg} \mathrm{L}^{-1}\right.$ in wet season and $2300 \mathrm{mg} \mathrm{L}^{-1}$ in dry season), which was also accompanied by higher water isotope contents in the dry compared to the wet season (Table 1). If this was caused by mixing with seawater, it would result in an increased seawater contribution of $7 \pm 5 \%$ for the dry season in GW11. Another reason could be short residence times of recharge from the unsaturated zone. Consequently, chloride originating from agricultural activities (irrigation, pomegranates) would be leached and diluted by winter precipitation with low isotope contents in the wet season.

Chloride concentrations were similar during both sampling campaigns in the dry and wet seasons at the bottom of the Köycegiz Lake ( 4500 and $4800 \mathrm{mg} \mathrm{L}^{-1}$ ), but differences were measured at the top (2200 and $\left.920 \mathrm{mg} \mathrm{L}^{-1}\right)$. High chloride concentrations were measured in seawater with 21700 and $20800 \mathrm{mg} \mathrm{L}^{-1}$ during the wet and dry season, respectively.

In the lagoon, chloride concentrations were generally higher in the dry season compared to the wet season (Fig. 5, Table 1). In the dry season, a clear layering was also supported by the chloride concentrations which were higher at the bottom of the lagoon compared to its top. When looking at the chloride isotope relationship, lagoon samples were mainly plotting in the triangle of groundwater, Köycegiz Lake water and seawater samples suggesting three main endmembers in the system (Fig. 5a). In the wet season, high chloride concentrations were only measured in the lagoon lake systems that also had enriched isotope contents (Fig. 5b). All other lagoon samples had chloride concentrations lower than $5000 \mathrm{mg} \mathrm{L}^{-1}$ plotting in the triangle of groundwater, Köycegiz Lake water and seawater samples suggesting three main endmembers in the system (Fig. 5b).

\subsection{Endmember mixing analysis}

The three component endmember mixing analysis was calculated for (i) the wet and dry season and (ii) for the top and bottom layer. The selected endmembers are given in Table 1 (asterisks) and the resulting source fractions for each location and season are given in Table 2.

For the wet season, average fractions of water sources were similar in the top and bottom of the lagoon (Fig. 6b). The arithmetic average (median) of groundwater, lake and seawater contribution was $0.24(0.25), 0.72(0.73)$ and 0.04 $(0.04)$ for the top and $0.21(0.22), 0.62(0.74)$, and 0.17 (0.02) for the bottom layer, respectively. Thus, the entire lagoon contained little seawater, and the main source was freshwater, either from the Köycegiz Lake or the groundwater. Certainly, we cannot exclude direct influence from precipitation having similar chemical composition compared to groundwater which will be further discussed below. High fractions of seawater were mainly found in the bottom of
Table 2. Average results of the three component endmember mixing analysis giving the contributions of groundwater $\left(f_{\mathrm{GW}}\right)$, lake water $\left(f_{\mathrm{LW}}\right)$ and seawater $\left(f_{\mathrm{SW}}\right)$ in the lagoon top and bottom for dry and wet seasons.

\begin{tabular}{|c|c|c|c|c|c|c|}
\hline & \multicolumn{3}{|c|}{ Dry season } & \multicolumn{3}{|c|}{ Wet season } \\
\hline & $f_{\mathrm{GW}}$ & $f_{\mathrm{LW}}$ & $f_{\mathrm{SW}}$ & $f_{\mathrm{GW}}$ & $f_{\mathrm{LW}}$ & $f_{\mathrm{SW}}$ \\
\hline \multicolumn{7}{|c|}{ Location - TOP } \\
\hline L01 & 0.020 & 0.975 & 0.005 & 0.210 & 0.780 & 0.010 \\
\hline L02 & 0.015 & 0.970 & 0.015 & 0.080 & 0.915 & 0.005 \\
\hline L03 & 0.070 & 0.905 & 0.025 & 0.265 & 0.720 & 0.015 \\
\hline L04 & 0.075 & 0.830 & 0.095 & 0.360 & 0.620 & 0.020 \\
\hline L05 & 0.000 & 0.559 & 0.441 & 0.255 & 0.675 & 0.070 \\
\hline L06 & 0.045 & 0.400 & 0.551 & 0.320 & 0.630 & 0.050 \\
\hline L07 & 0.140 & 0.530 & 0.335 & 0.210 & 0.775 & 0.015 \\
\hline L08 & 0.000 & 0.189 & 0.811 & 0.320 & 0.640 & 0.040 \\
\hline L09 & 0.000 & 0.431 & 0.569 & 0.130 & 0.835 & 0.035 \\
\hline L10 & 0.000 & 0.447 & 0.549 & 0.260 & 0.730 & 0.010 \\
\hline L11 & 0.000 & 0.335 & 0.665 & 0.605 & 0.290 & 0.105 \\
\hline L12 & 0.000 & 0.513 & 0.488 & 0.230 & 0.665 & 0.105 \\
\hline L13 & 0.000 & 0.307 & 0.693 & 0.135 & 0.790 & 0.070 \\
\hline L14 & 0.000 & 0.332 & 0.668 & 0.065 & 0.825 & 0.110 \\
\hline L15 & 0.030 & 0.650 & 0.320 & 0.250 & 0.665 & 0.085 \\
\hline L22 & 0.055 & 0.580 & 0.360 & 0.240 & 0.745 & 0.015 \\
\hline L29 & 0.000 & 0.468 & 0.532 & 0.150 & 0.840 & 0.010 \\
\hline L33 & 0.040 & 0.400 & 0.560 & 0.265 & 0.720 & 0.015 \\
\hline \multicolumn{7}{|c|}{ Location - BOTTOM } \\
\hline L01 & 0.335 & 0.420 & 0.245 & .225 & 0.765 & 0.010 \\
\hline L02 & 0.020 & 0.645 & 0.335 & 0.220 & 0.775 & 0.005 \\
\hline L03 & 0.360 & 0.380 & 0.258 & 0.235 & 0.760 & 0.005 \\
\hline L04 & 0.088 & 0.140 & 0.772 & 0.425 & 0.555 & 0.020 \\
\hline L05 & 0.056 & 0.050 & 0.894 & 0.200 & 0.460 & 0.340 \\
\hline L06 & 0.100 & 0.250 & 0.650 & 0.250 & 0.695 & 0.050 \\
\hline L07 & 0.073 & 0.075 & 0.852 & 0.355 & 0.630 & 0.015 \\
\hline L08 & 0.145 & 0.000 & 0.855 & 0.115 & 0.865 & 0.020 \\
\hline L09 & 0.108 & 0.015 & 0.874 & 0.130 & 0.815 & 0.060 \\
\hline L10 & 0.061 & 0.168 & 0.770 & 0.280 & 0.705 & 0.015 \\
\hline L11 & 0.000 & 0.349 & 0.651 & 0.375 & 0.480 & 0.145 \\
\hline L12 & 0.030 & 0.305 & 0.674 & 0.350 & 0.505 & 0.145 \\
\hline L13 & 0.000 & 0.150 & 0.850 & 0.025 & 0.000 & 0.975 \\
\hline L14 & 0.060 & 0.060 & 0.880 & 0.025 & 0.000 & 0.975 \\
\hline L15 & 0.000 & 0.300 & 0.700 & 0.110 & 0.815 & 0.075 \\
\hline L22 & 0.107 & 0.055 & 0.838 & 0.205 & 0.785 & 0.010 \\
\hline L29 & 0.000 & 0.175 & 0.825 & 0.135 & 0.855 & 0.010 \\
\hline L33 & 0.045 & 0.005 & 0.950 & 0.150 & 0.675 & 0.175 \\
\hline
\end{tabular}

the lagoon lake systems (Fig. 7d, Table 2). The more shallow Alagöl lake (L5; $3.3 \mathrm{~m}$ ) contained about $34 \%$ seawater and $98 \%$ seawater were calculated for the deeper Sülüngür Lake (L13, L14; 3.6-5.4 m) (Table 2). The branches of the lagoon showed slightly increased saltwater contributions $(9 \%$ top layer, $10 \%$ bottom layer) compared the Dalyan channel locations ( $2 \%$ top layer, $3 \%$ bottom layer) (Fig. 7c, d). Besides, no variability in seawater and freshwater contribution 

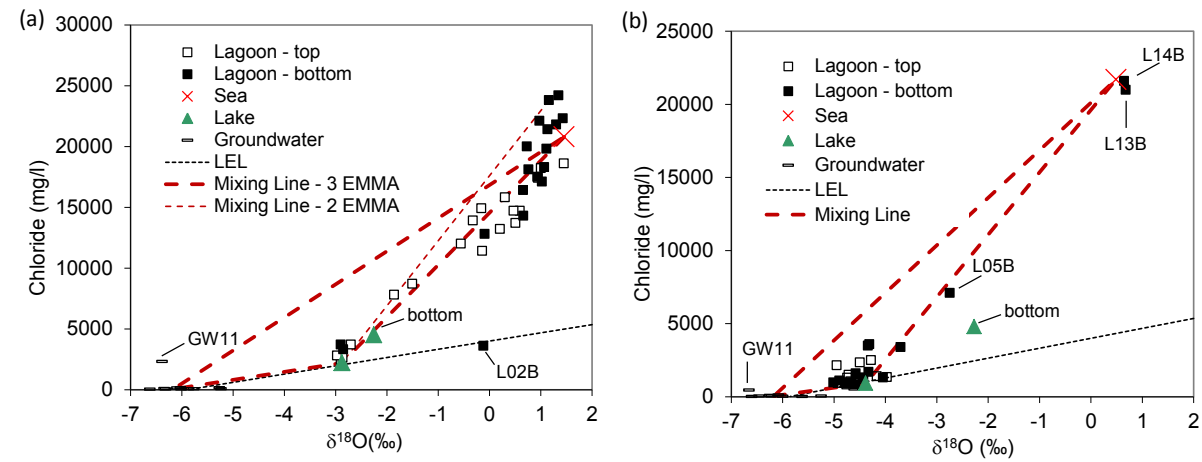

Figure 5. Chloride concentrations and $\delta^{18} \mathrm{O}$ ratios for (a) dry season and (b) wet season sampling campaign; the dashed lines connect the three (bold) or two (light) endmembers used for the mixing analysis.
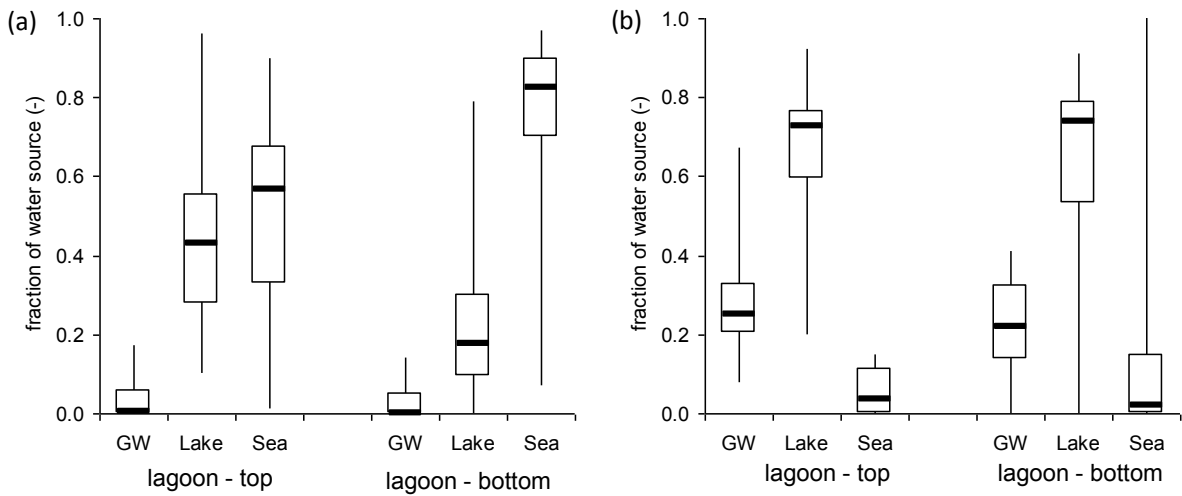

Figure 6. Fractions of different sources of the lagoon water for (a) dry and (b) wet season sampling campaign.

was found with distance from the shore line (Fig. 7c, d); the error bars in Fig. 7 indicate the variability of the results when using $\delta^{18} \mathrm{O}$ and $\mathrm{Cl}^{-}$or $\delta^{18} \mathrm{O}$ and salinity as signatures for the endmember mixing analysis.

For the dry season, average fractions of water sources were different compared to the wet season, and more variability was found within the lagoon and when comparing top and bottom of the lagoon (Fig. 6a). The arithmetic average (median) of groundwater, lake and seawater contribution was $0.03(0.01), 0.54(0.43)$ and $0.43(0.57)$ for the top and 0.09 (0.00), $0.20(0.18)$, and $0.71(0.83)$ for the bottom layer, respectively. Particularly the contribution of groundwater was little during the dry season (Table 2, Fig. 6a). The lagoon contained more seawater in the dry season compared to the wet season and at the bottom compared to the top layers. Further, there was a gradient of saltwater contribution in the lagoon with nearest distance to the shoreline (Fig. 7a, b). The closer to the sea, the higher is the fraction of seawater. Still, the lagoon lake systems contained on average higher fractions of saltwater (60\%, top; $88 \%$, bottom) compared to the Dalyan channel locations (35\%, top; 69\%, bottom) (Fig. 7a). The branches of the lagoon seem to be more mixed compared to lake and channel locations (Fig. 7a, b) containing on average 51 and $67 \%$ of seawater on top and bottom, respectively.

\section{Discussion}

The results clearly indicated differences in contribution of various water sources in the dry and wet seasons. We proved that it is an extremely dynamic system dominated by seawater in the dry season $(>55 \%)$ and freshwater in the wet season $(>95 \%)$. Lecuyer et al. (2012) also found higher contribution of freshwater (62\%) compared to seawater (38\%) in the winter (the wet season) assuming seawater and stream water as sole endmembers. Still, their open water lagoon on the Turkish coast was generally more dominated by seawater throughout the rest of the year; particularly in summer and autumn freshwater contribution seemed to be mostly absent and hypersaline conditions formed due to evaporation of seawater. In contrast, our study site had freshwater influence even in the dry season. Here, the freshwater mainly came from the upstream lake and groundwater contribution was minor. Thus, the lagoon is groundwater influenced only in the wet season. In addition, we cannot exclude direct precipitation as additional water source for the wet season; due to little precipitation in summer ( $3 \mathrm{~mm}$ in average) its influence during the dry season was assumed to be negligible. We expect that winter precipitation has similar isotopic composition compared to the local groundwater and therefore, any 

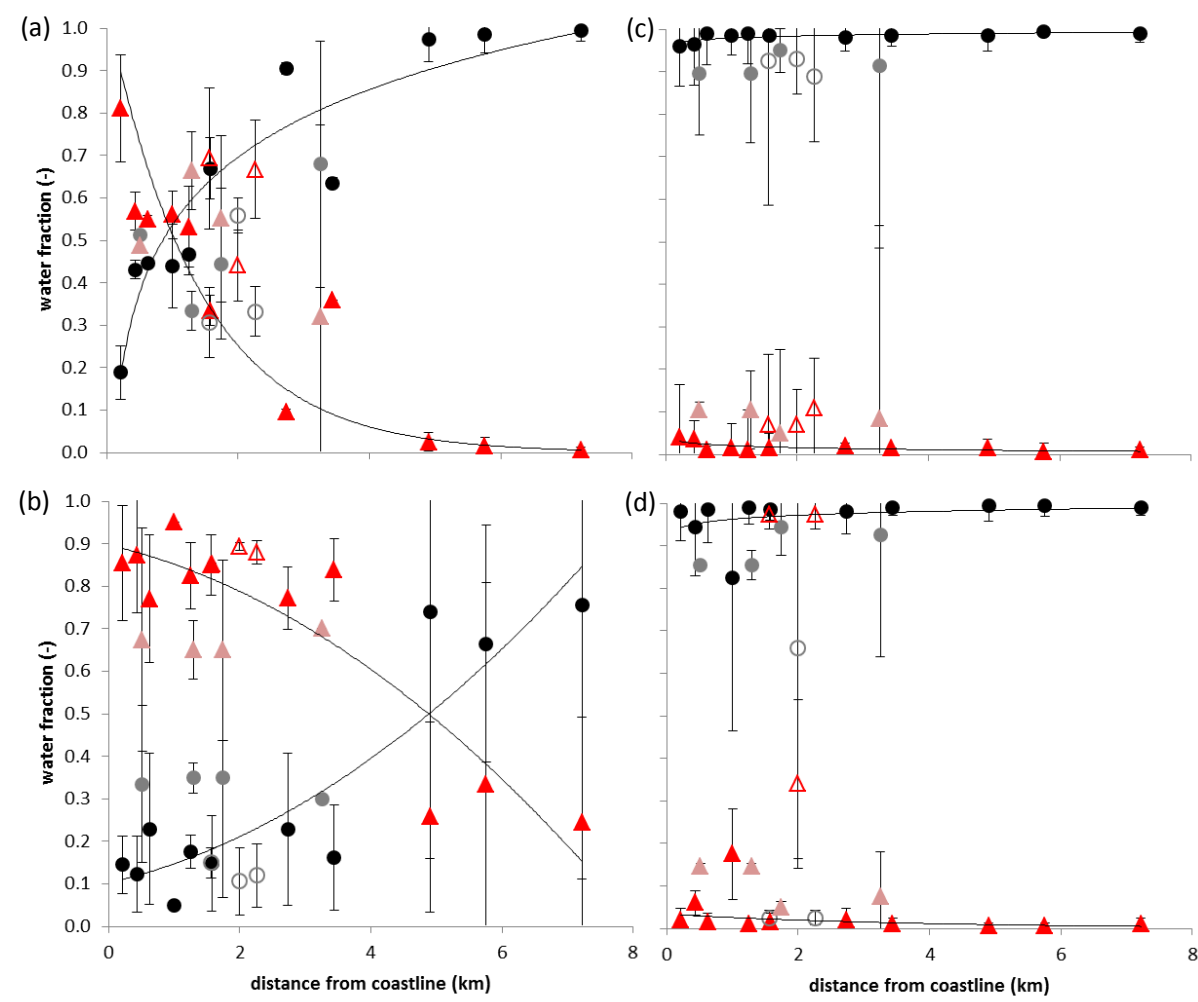

Figure 7. Changing fractions of freshwater (circles) and marine water (triangles) with distance from the coastline for (a) the top layer in the dry season, (b) bottom layer in the dry season, (c) top layer in the wet season, (d) bottom layer in the wet season; closed dark symbols indicate locations at the main lagoon channel, open symbols indicate surrounding lake locations and closed light symbols indicate their inflow/outflow connections to the lagoon system; error bars were determined from variability of endmember mixing analysis using salinity and chloride data individually in combination with $\delta^{18} \mathrm{O}$.

contribution of direct precipitation was hidden in the groundwater term. However, this hidden precipitation is suggested to be little when looking at the upstream Köycegiz Lake water balance and the size of the entire catchment $\left(960 \mathrm{~km}^{2}\right)$ compared to the lagoon size $\left(130 \mathrm{~km}^{2}\right)$. In the Köycegiz Lake precipitation is for example more than 15 times smaller compared to its outflow into the lagoon (Bayari et al., 1995). Additionally, we sampled during a period without precipitation and therefore, our results are representative for base flow conditions in the lagoon system.

We found different dynamics for the bottom and top layers and also for the different locations in the lagoon. Particular seasonal changes were dramatic in the main Dalyan channel closer to the coast and at its bottom (Fig. 7b, d). We assume that the terrestrial water levels (groundwater, lake, lagoon) declined in the dry season influencing the hydraulic gradients and also density driven flow of the seawater further inland. Here, the intrusion reached up to $4 \mathrm{~km}$ inland at the bottom of the lagoon. A 50:50 mixing of salt and freshwater is expected for bottom layers at $4.9 \mathrm{~km}$ distance from the coast (Fig. 7b) and for top layer at $1 \mathrm{~km}$. The freshwater (seawater) mixing relationship with distance from the shoreline was best approximated by logarithmic (exponential) function (Fig. 7).
Still, the saltwater intrusion was mainly restricted to the lagoon system itself as the groundwater wells were unaffected by seawater influence in the dry season. Our findings are in agreement with previous studies on hydrodynamic modelling in this area (Ekdal et al., 2005; Erturk et al., 2003; Gönenc et al., 2004). In these studies, similar spatial and temporal dynamics were obtained concluding that intrusion causes strong stratification throughout almost the entire lagoon especially in the dry season. The flow direction in the upper layer was from Köycegiz Lake towards the Mediterranean Sea, while flow in the bottom layer was from the Mediterranean Sea towards the Köycegiz Lake. Barotrophy was found to be the driving force of the surface flow, whereas the bottom flow was baroclinic (Gönenc et al., 2004).

In the present study, the endmember mixing analysis yielded lower uncertainties in the wet compared to the dry season (Fig. 7), which is also obvious when looking at the endmember mixing triangles in Fig. 5. For the wet season, the composition of the seawater endmember was adequate (Fig. 5b). For the dry season though, higher chloride concentration as well as more enriched $\delta^{18} \mathrm{O}$ were expected (Fig. 5a) and thus, samples plot outside of the mixing triangle. This indicates that either the endmember was chosen wrongly 
or/and evaporation is crucial. Evaporation of surface water explains an increase in salt concentrations and isotopic enrichment like observed in a close-by lagoon (Lecuyer et al., 2012). Even though evaporation was actually considered indirectly by the lake endmember, evaporation of lagoon water could be higher due to the smaller water volume compared to the lake. Therefore, a stronger enrichment of stable isotopes explains the deviations of top surface water samples located outside of the mixing triangle in the dry season (Fig. 5a). However, also enrichment of bottom samples was found in the dry season which is unusual and cannot be explained by evaporation only. Even hypersaline conditions in some of the bottom samples were found (compared to the seawater sample). Interestingly, the slope of the $\mathrm{Cl}^{-}-\delta^{18} \mathrm{O}$ relationship was steeper for bottom compared to top lagoon samples. It remained unknown whether an additional water source in the system has to be considered which was of geothermal origin as found for Köycegiz Lake (Bayari et al., 1995) and as common in this area due to geology and tectonic activity (Mutlu and Gülec, 1998).

Further assessing the two discussed uncertainties (i.e. choice of endmember and evaporation) and neglecting the small contributions of groundwater to the lagoon, a two component endmember mixing analysis was additionally conducted after correction of the data due to evaporation (Fig. 5a; 2 EMMA mixing line). First, the seawater surface sample was replaced by the deep lagoon sample at the very end of the Dalyan Channel exiting into the sea (L08B). Here, chloride concentrations and also isotopes were even higher compared to the seawater sample. It was measured in the depth and we expect it to be representative of the actual seawater not influenced by any freshwater compared to the actual seawater sample from the surface. Therefore, L08B could be used as endmember for the dry season being representative for seawater too. Second, all lagoon samples were forced onto the mixing line accounting for enrichment due to evaporation. Therefore, an Evaporation Line was calculated considering the top lake sample for both seasons only $\left(\mathrm{Cl}^{-}=670 \delta^{18} \mathrm{O}+4000\right)$. Here, $10 \%$ increase in chloride was accompanied by $3.4 \%$ increase in $\delta^{18} \mathrm{O}$. This regression was used to correct the lagoon data back to the mixing line. Similar procedures were done with salinity and isotope data (data not shown). The difference between measured and corrected chloride concentrations (salinity) was further used to do a mass balance calculation. Thus, relative, average evaporation were estimated at all sites (Table 3); they have to be seen as relative because the actual surface Köycegiz Lake water already comprised evaporation which was estimated to $6.8 \%$ (Bayari et al., 1995). The calculated evaporation in the lagoon ranged from 0 to $7 \%$. There was only one outliner L2B (Fig. 5a) with high chloride concentrations resulting in $54 \%$ evaporation based on chloride data; but with $0.2 \%$ evaporation based on salinity data. We attributed it to erroneous chloride analysis rather than to water influenced by geothermal origin because of differences in chemical and iso-
Table 3. Average results of two-component endmember mixing analysis giving the contributions of lake water $\left(f_{\mathrm{LW}}\right)$ and seawater $\left(f_{\mathrm{SW}}\right)$ in the lagoon top and bottom for the dry season; average relative percentages of evaporation calculated for dry season based on data correction (details given in text).

\begin{tabular}{|c|c|c|c|}
\hline \multicolumn{2}{|c|}{$\begin{array}{l}f_{\mathrm{LW}} \\
\text { Location }-\mathrm{TOP}\end{array}$} & $f_{\mathrm{SW}}$ & $\begin{array}{l}\text { evapo- } \\
\text { ration }(\%)\end{array}$ \\
\hline L01T & 0.993 & 0.007 & - \\
\hline L02T & 0.989 & 0.011 & 0.1 \\
\hline L03T & 0.975 & 0.025 & - \\
\hline L04T & 0.913 & 0.087 & - \\
\hline L05T & 0.540 & 0.460 & 5.3 \\
\hline L06T & 0.469 & 0.531 & 3.3 \\
\hline L07T & 0.689 & 0.311 & - \\
\hline L08T & 0.179 & 0.821 & 3.7 \\
\hline L09T & 0.389 & 0.611 & 4.7 \\
\hline L10T & 0.412 & 0.588 & 4.7 \\
\hline $\mathrm{L} 11 \mathrm{~T}$ & 0.376 & 0.624 & 3.1 \\
\hline $\mathrm{L} 12 \mathrm{~T}$ & 0.472 & 0.528 & 5.0 \\
\hline L13T & 0.292 & 0.708 & 4.3 \\
\hline L14T & 0.312 & 0.688 & 4.5 \\
\hline $\mathrm{L} 15 \mathrm{~T}$ & 0.472 & 0.528 & 2.1 \\
\hline $\mathrm{L} 22 \mathrm{~T}$ & 0.671 & 0.329 & 0.7 \\
\hline L29T & 0.413 & 0.587 & 5.0 \\
\hline L33T & 0.483 & 0.517 & 1.6 \\
\hline \multicolumn{4}{|c|}{ Location - BOTTOM } \\
\hline L01B & 0.598 & 0.402 & - \\
\hline L02B & 0.667 & 0.333 & 0.2 \\
\hline L03B & 0.494 & 0.506 & - \\
\hline L04B & 0.198 & 0.802 & 1.4 \\
\hline L05B & 0.075 & 0.925 & 1.9 \\
\hline L06B & 0.365 & 0.635 & 2.4 \\
\hline L07B & 0.126 & 0.874 & 1.7 \\
\hline L08B & 0.000 & 1.000 & - \\
\hline L09B & 0.016 & 0.984 & 0.8 \\
\hline L10B & 0.156 & 0.844 & 2.9 \\
\hline L11B & 0.312 & 0.688 & 4.8 \\
\hline L12B & 0.315 & 0.685 & 3.6 \\
\hline L13B & 0.194 & 0.806 & 2.6 \\
\hline L14B & 0.181 & 0.819 & 1.4 \\
\hline L15B & 0.374 & 0.626 & 4.2 \\
\hline L22B & 0.100 & 0.900 & 0.8 \\
\hline L29B & 0.226 & 0.774 & 2.7 \\
\hline L33B & 0.118 & 0.882 & 1.5 \\
\hline
\end{tabular}

tope characteristics compared to geothermal springs in this area (Bayari et al., 1995). The results of the two component endmember mixing approach yielded similar fractions of freshwater and marine water as the three component approach (Fig. 8, Table 3). Considering uncertainties of the methods (Fig. 7), no distinct differences in freshwater or saltwater sources were found hence. This suggested that for the dry season both groundwater and evaporation could be neglected in the system. Still, the correction of the data due to 

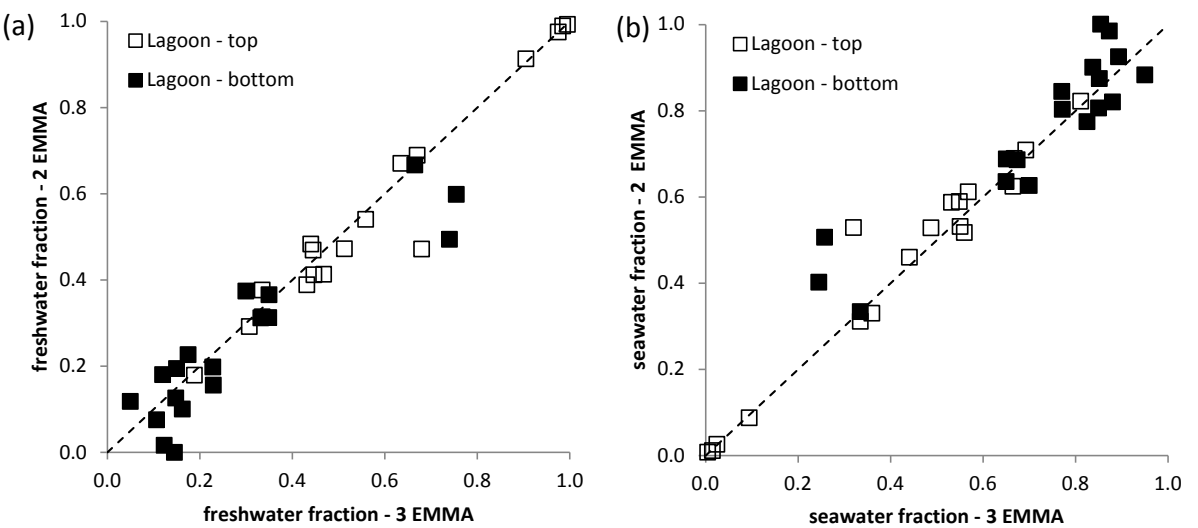

Figure 8. Fractions of freshwater (a) and seawater (b) contributions in the top and bottom lagoon samples calculated from two and three endmember mixing approaches; dashed line gives $1: 1$ line.

evaporation is kind of arbitrary, forcing all values onto the mixing line. Only knowing the actual evaporation at individual locations and in the lake would help to adequately correct the data which even might push some results into the threeendmember mixing triangle. Hence, fractions of groundwater even in the dry season would be underestimated by the current procedure of data correction.

Independent on the mixing approach, there were not only spatial differences in top and bottom layers for the main Dalyan channel, but also differences between different locations within the lagoon. The main channel responded quickly to changes and showed seasonal dynamics. The lake structures in the lagoon system were, however, responding differently. Here, the saltwater was found in the bottom layer even in the wet season indicating maintenance of stratification; particularly in the larger and deeper Sülüngür Lake. A partial mixing was found for the smaller and shallower Alagöl Lake where saltwater contribution was $34 \%( \pm 20 \%)$. Also the side branches of the lagoon had less extreme changes as the main channel indicating higher water transit times in these areas and thus slower renewal. Particularly in the dry season, the contribution of both fresh and saltwater was about equal for the top layer and two-thirds to one-third for the bottom layer and independent on the distance to the coastline. These findings are in agreement with residence time calculations of a previous study (Ekdal, 2008) using the Water Quality Analysis Simulation Model. Average residence times of Sülüngür Lake (especially deeper parts of the lake) were considerably higher (16-700 d) when compared to other parts of the system (>16 d). The residence time in Alagöl (5-16 d) was also high when compared to the main channel. The main channel had a low residence time $(<5 \mathrm{~d})$, which showed the dynamic characteristics of the lagoon, and which is in agreement with the results of this study.

\section{Conclusions}

We showed that environmental tracers can be used not only to identify but also to quantify different water sources in a lagoon ecosystem. Freshwater and marine water sources were strongly dynamic and heterogeneous in time and space. We found different water sources and mixing ratios for dry and wet seasons and for top and bottom layers in the lagoon. In the wet season, freshwater was found in all locations and all depths except at the bottom of a larger lagoon lake. Generally, the freshwater was a mixture of upstream lake water and groundwater. The groundwater influence was, however, mainly restricted to the wet season and almost absent in the dry season. It was assumed that water levels decline and the input of seawater in the lagoon gets more pronounced; particularly in the main flow channel of the lagoon. Here, a clear stratification was observed in the dry season only, with higher saltwater contributions at the lagoon bottom compared to its top. At some of these locations, the lagoon changed from a complete freshwater system to a complete saltwater system which certainly has implications for the ecosystem which has to be highly adapted to such dynamic conditions. At side branches and lake structures in this wetland type lagoon, changes in water sources were less extreme and variable. From these findings, we conclude that the lagoon and the groundwater could be vulnerable to certain global change scenarios like sea level rise and decrease in precipitation. Consequently, water levels in the groundwater and lake would drop and the seawater influence would increase in the lagoon system affecting its ecosystem functions and probably also affecting the groundwater quality. In future, it needs to be analysed how the ecosystem itself reacts to changes of water sources to investigate the vulnerability of the ecosystem functions. 
Acknowledgements. Funding by the EU GENESIS Project no. 226536 (FP7-ENV-2008-1) is kindly acknowledged. We would also like to acknowledge Melike Gürel, Nusret Karakaya, Ali Ertürk, Gökhan Cüceloglu and Çigdem Güzel for their contribution in taking the samples during the field studies. We thank one anonymous reviewer and K. Rozanski for their helpful comments that improved the quality of the manuscript.

Edited by: P. Wachniew

\section{References}

Alongi, D. M.: Coastal Ecosystem Processes, CRC Press, Boca Raton, 1998.

Anthony, A., Atwood, J., August, P., Byron, C., Cobb, S., Foster, C., Fry, C., Gold, A., Hagos, K., Heffner, L., Kellogg, D. Q., LellisDibble, K., Opaluch, J. J., Oviatt, C., Pfeiffer-Herbert, A., Rohr, N., Smith, L., Smythe, T., Swift, J., and Vinhateiro, N.: Coastal Lagoons and Climate Change: Ecological and Social Ramifications in US Atlantic and Gulf Coast Ecosystems, Ecol. Soc., 14, 8, 2009.

Barnes, R. S. K.: Coastal lagoons, Cambridge University press, Cambridge, UK, 106 pp., 1980.

Bayari, S. C., Kazanci, N., Koyuncu, H., Çaglar, S. S., and Gökçe, D.: Determination of the origin of the waters of Köycegiz Lake, Turkey, J. Hydrol., 166, 171-191, doi:10.1016/00221694(94)02554-O, 1995.

Bayari, C. D., Kurittas, T., and Tezcan, L.: Dynamics of Lake Köycegiz, SW Turkey: An Environmental Isotopic and Hydrogeochemical Study, in: Use of isotope techniques in lake dynamics investigations, IAEA-TECDOC-1206, Vienna, Austria, 2001.

Ekdal, A.: Water Quality Modeling of Köycegiz - Dalyan Lagoon, Ph.D. thesis, Istanbul Technical University, Istanbul, Turkey, 236 pp., 2008.

Bowen, G. J. and Wilkinson, B.: Spatial distribution of $\delta^{18} \mathrm{O}$ in meteoric precipitation, Geology, 30, 315-318, 2002.

Ekdal, A., Gurel, M., Erturk, A., and Tanik, A.: Hydrodynamic and Water Quality Modeling Approach for a Dynamic Lagoon System, Environmental Hydraulics and Sustainable Water Management, Proceedings, 15-18 December, Hong Kong, China, 621627, 2005.

Erturk, A., Gurel, M., Koca, D., Ekdal, A., Tanik, A., Seker, D. Z., Kabdasli, S., and Gönenc, I. E.: Determination of Model Dimensions for a Complex Lagoon System - A Case Study From Turkey, Proceedings of XXX IAHR Congress Water Engineering and Research in a learning Society: Modern Developments and Traditional Concepts, 24-29 August 2003, Thessaloniki, Greece, 53-60, 2003.

Graciansky, P. C.: Stratigraphy of the overlapped units of the Lycien Nappes in the Teke Peninsula and their position within the Dinaro-Taurids, Bull. Miner. Res. Explor. Inst., Ankara, 71, 7392, 1968 (in Turkish).

Gattacceca, J. C., Vallet-Coulomb, C., Mayer, A., Claude, C., Radakovitch, O., Conchetto, E., and Hamelin, B.: Isotopic and geochemical characterization of salinization in the shallow aquifers of a reclaimed subsiding zone: The southern Venice Lagoon coastland, J. Hydrol., 378, 46-61, doi:10.1016/j.jhydrol.2009.09.005, 2009.
Gönenc, I. E., Tanik, A., Seker, D. Z., Gurel, M., Erturk, A., Ekdal, A., Yuceil, K., Kose, C., Beyazgul, M., and Bilir, L. Z.: Ecosystem modeling for the sustainable management of lagoons, Final Report, The Scientific and Technical Research Council of Turkey, TUBITAK YDABCAG Project No: 100Y047, Ankara, 2004.

Google Earth, available at: http://www.google.com/earth/, last access: 25 May 2014.

Gurel, M., Tanik, A., Erturk, A., Dogan, E., Okus, E., Seker, D. Z., Ekdal, A., K., Y., Bederli Tumay, A., Karakaya, N., Beler Baykal, B., and Gönenc, I. E.: Köycegiz - Dalyan Lagoon: A case study for sustainable use and development, in: Coastal Lagoons: Ecosystem Processes and Modeling for Sustainable Use and Development, edited by: Gönenc, I. E. and Wolflin, J., CRC Press, Boca Raton, Florida, 440-474, 2005.

Kløve, B., Ala-Aho, P., Bertrand, G., Gurdak, J. J., Kupfersberger, H., Kværner, J., Muotka, T., Mykrä, H., Preda, E., Rossi, P., Uvo, C. B., Velasco, E., and Pulido-Velazquez, M.: Climate change impacts on groundwater and dependent ecosystems, J. Hydrol., 518, Part B, 250-266, 2014.

Lecuyer, C., Bodergat, A. M., Martineau, F., Fourel, F., Gurbuz, K., and Nazik, A.: Water sources, mixing and evaporation in the Akyatan lagoon, Turkey, Estua. Coastal Shelf Sci., 115, 200-209, doi:10.1016/j.ecss.2012.09.002, 2012.

Longinelli, A. and Selmo, E.: Isotopic composition of precipitation in Italy: a first overall map, J. Hydrol., 270, 75-88, 2003.

Lykoudis, S. P. and Argiriou, A. A.: Gridded data set of the stable isotopic composition of precipitation over the eastern and central Mediterranean, J. Geophys. Res.-Atmos., 112, D18107, doi:10.1029/2007JD008472, 2007.

Mutlu, H. and Gülec, N.: Hydrogeochemical outline of thermal waters and geothermometry applications in Anatolia (Turkey), J. Volcanol. Geotherm. Res., 85, 495-515, doi:10.1016/s03770273(98)00068-7, 1998.

Niencheski, L. F. H., Windom, H. L., Moore, W. S., and Jahnke, R. A.: Submarine groundwater discharge of nutrients to the ocean along a coastal lagoon barrier, Southern Brazil, Mar. Chem., 106, 546-561, doi:10.1016/j.marchem.2007.06.004, 2007.

Pérez-Ruzafa, A., Marcos, C., and Pérez-Ruzafa, I. M.: Mediterranean coastal lagoons in an ecosystem and aquatic resources management context, Phys. Chem. Earth, 36, 160-166, doi:10.1016/j.pce.2010.04.013, 2011a.

Pérez-Ruzafa, A., Marcos, C., Pérez-Ruzafa, I., and Pérez-Marcos, M.: Coastal lagoons: "transitional ecosystems" between transitional and coastal waters, J. Coast. Conserv., 15, 369-392, doi:10.1007/s11852-010-0095-2, $2011 \mathrm{~b}$.

Remane, A. and Schlieper, C.: Biology of Brackish Water, Wiley Interscience, New York, 372 pp., 1971.

Santos, I. R., Machado, M. I., Niencheski, L. F., Burnett, W., Milani, I. B., Andrade, C. F. F., Peterson, R. N., Chanton, J., and Baisch, P.: Major ion chemistry in a freshwater coastal lagoon from southern Brazil (Mangueira Lagoon): Influence of groundwater inputs, Aquat. Geochem., 14, 133-146, doi:10.1007/s10498008-9029-0, 2008a.

Santos, I. R., Niencheski, F., Burnett, W., Peterson, R., Chanton, J., Andrade, C. F. F., Milani, I. B., Schmidt, A., and Knoeller, K.: Tracing anthropogenically driven groundwater discharge into a coastal lagoon from southern Brazil, J. Hydrol., 353, 275-293, doi:10.1016/j.jhydrol.2008.02.010, 2008b. 
Schmidt, A., Santos, I. R., Burnett, W. C., Niencheski, F., and Knöller, K.: Groundwater sources in a permeable coastal barrier: Evidence from stable isotopes, J. Hydrol., 406, 66-72, doi:10.1016/j.jhydrol.2011.06.001, 2011.
Vreca, P., Bronic, I. K., Horvatincic, N., and Baresic, J.: Isotopic characteristics of precipitation in Slovenia and Croatia: Comparison of continental and maritime stations, J. Hydrol., 330, 457469, 2006.

WISER, available at: http://www-naweb.iaea.org/napc/ih/IHS_ resources_isohis.html, last access: 19 May 2014. 